\title{
PENGGUNAAN PUPUK CAIR Chromolaena odorata DAN KALIUM DALAM MENEKAN KEHAMPAAN DAN MENINGKATKAN HASIL PADI UNGU BLACK MADRAS
}

\author{
Application of Chromolaena odorata Liquid Fertilizer and Potassium in Reducing Grain \\ Voidness and Improving Yield of Black Madras Purple Rice \\ Jamilah $^{1 *}$, R. Ahmad', M. Ernita ${ }^{2}$ \\ ${ }^{1}$ Fakultas Pertanian, Universitas Tamansiswa Padang \\ ${ }^{2}$ Program Studi Agroteknologi, Fakultas Pertanian, Universitas Tamansiswa Padang \\ Jl. Tamansiswa No. 9 Padang Sumbar 25138 \\ *Email : jamilahfatika@gmail.com
}

Diterima 6 Januari 2020/Disetujui 12 Maret 2020

\begin{abstract}
ABSTRAK
Padi ungu Black Madras merupakan varietas padi yang masih belum banyak dibudidayakan dan dikonsumsi di Indonesia. Salah satu keunggulan padi ini adalah kadar gulanya rendah, sehingga cocok dikonsumsi oleh penderita diabetes dan sakit jantung. Pemberian pupuk sangat berpengaruh terhadap pertumbuhan, kehampaan dan hasil tanaman, termasuk padi ungu Black Madras. Tujuan penelitian ini adalah untuk mengetahui pengaruh pemberian pupuk cair Chromolaena odorata dan kalium dalam menekan kehampaan dan meningkatkan hasil padi ungu Black Madras. Percobaan dilakukan di Kelurahan Lubuk Lintah Kota Padang dengan ketinggian tempat $\pm 20 \mathrm{~m}$ dpl. Rancangan penelitian yang digunakan adalah Rancangan Kelompok Lengkap Teracak (RKLT) Faktorial 3 ulangan. Perlakuan terdiri dari pupuk cair C.odorata dengan konsentrasi 0, 25 dan $50 \mathrm{ml} \mathrm{L}^{-1}$ serta pupuk $\mathrm{KCl}(60 \% \mathrm{~K} 2 \mathrm{O})$ dengan taraf $0,50,100$ dan $150 \mathrm{~kg} \mathrm{ha}^{-1}$. Hasil percobaan menunjukkan bahwa pemberian 25 $\mathrm{ml} \mathrm{L}{ }^{-1}$ pupuk cair $C$. odorata efektif dalam menekan kehampaan padi hingga $55 \%$. Pemberian pupuk kalium sebanyak $100 \mathrm{~kg} \mathrm{ha}^{-1}$ yang diiringi dengan $25 \mathrm{ml} \mathrm{L}^{-1}$ PCCO memberikan hasil GKP tertinggi yaitu $7,88 \mathrm{~kg} \mathrm{ha}^{-1}$.
\end{abstract}

Kata kunci: pupuk cair Chromolaena odorata, padi ungu Black Madras, pupuk $\mathrm{KCl}$

\section{ABSTRACT}

Black Madras purple rice is a rice variety that is still not widely cultivated and consumed in Indonesia. One of the advantages of this rice is low sugar content, making it suitable for consumption by people with diabetes and heart disease. Fertilizers are very influential on growth, garin void and yield of crops, including Black Madras purple rice. The aimed of this research was to determine the effect of Chromolaena odorata and potassium liquid fertilizer in reducing voidness and increasing yield of Black Madras purple rice. The experiment was conducted in Kelurahan Lubuk Lintah, Padang with a height of $\pm 20 \mathrm{~m}$ above sea level. The research design used was a Factorial Complete Randomized Design with 3 replications. The treatments consisted of liquid C.odorata fertilizer with concentrations of 0 , 25 and $50 \mathrm{ml} \mathrm{L-1}$ and $\mathrm{KCl}$ fertilizer (60\% K2O) with levels of 0, 50, 100 and $150 \mathrm{~kg} \mathrm{ha}-1$. The results showed that the administration of $25 \mathrm{ml} \mathrm{L}^{-1}$ liquid fertilizer C.odorata was effective and efficient in reducing empty grain to $55 \%$. The application of $100 \mathrm{~kg} \mathrm{ha}^{-1}$ of KCl fertilizer and $25 \mathrm{ml} \mathrm{L}^{-1}$ of liquid feritilizer C.odorata was the optimum recommendation for purple rice plants and produced $7.88 \mathrm{th} \mathrm{h}^{-1}$ dry grain harvest. 


\section{PENDAHULUAN}

Padi ungu Black Madras merupakan varietas padi yang memiliki warna daun ungu, tetapi warna berasnya tetap putih. Tipe padi ini mempunyai umur panen berkisar antara 85-95 hari, tinggi tanaman $100 \mathrm{~cm}$, tekstur nasi agak pulen, daun bendera tegak, potensi hasil 6-7 ton ha ${ }^{-1}$ (Nutani 2018). Black Madras pertama kali dikembangkan di Korea dan Jepang. Salah satu keunggulan padi Black Madras adalah kandungan gula yang rendah, sehingga cocok untuk penderita diabetes, penderita jantung dan juga untuk bahan kosmetik. Harga gabah yang mahal memberikan prospek yang cerah dikembangkan, karena padi ini juga tergolong tahan kekeringan.

Benih padi Black Madras dijual sebagai ornamental rice (padi hias) di negara berkembang, padahal padi ini juga baik untuk dikonsumsi. Tanaman padi ini ditumbuhkan dalam media pot untuk penghias pekarangan rumah, sehingga benih padi dijual seperti harga bibit tanaman hias yang cukup mahal. Setiap $50 \mathrm{~g}$ benih, dijual dengan harga $£ 27.38$ atau setara Rp. 425.000,- (King Seeds, 2019)

Pemberian pupuk selain melalui tanah juga dapat melalui daun. (Gutiérrezgamboa et al. 2016), (Gutiérrez-gamboa et al. 2017), (Shahid et al. 2017) menjelaskan bahwa aplikasi pupuk cair dapat langsung ke sumber yang membutuhkannya. Pupuk cair masuk melalui stomata atau kutikula daun kemudian mekanisme serapan tidak berbeda dengan melalui serapan akar. Menurut Jamilah (2017), keuntungan pemberian pupuk melalui daun diantaranya adalah biaya rendah, respon tanaman cepat, kurangnya fiksasi tanah, bebas dari serapan akar, penggunaan pupuk hanya sedikit dan memiliki kemampuan bergabung dengan bahan kimia pertanian lainnya.

Salah satu jenis pupuk cair yang dapat digunakan adalah yang berasal dari semak Chromolaena odorata. Bahan tersebut dapat difermentasi dengan bahan lain seperti pupuk kandang, batang pisang, sabut kelapa, urine sapi, air kelapa dan buah pepaya. Jamilah dan Juniarti (2014), Jamilah
(2015), Jamilah et al. (2017), melaporkan bahwa pupuk cair jauh lebih efektif dan efisien dibandingkan dengan pupuk buatan. Selain itu, pupuk cair juga merupakan bahan organik yang tergolong ramah lingkungan.

Pupuk cair Chromolaena odorata dihasilkan dari fermentasi bergantian dari perombakan antara anaerob dan aerob secara berselang-seling, yang diperkaya oleh berbagai limbah pertanian. Jenis limbah yang digunakan antara lain sabut kelapa sebagai sumber $\mathrm{K}$, batang pisang yang mengandung zat pengatur tumbuh, pupuk kandang sapi sebagai sumber $\mathrm{N}$ dan air kelapa yang mengandung zat pengatur tumbuh auksin (Jamilah dan Kurniawan 2018).

Berdasarkan laporan Akriweldi (2017), padi ungu Black Madras yang diberi $100 \mathrm{ml} \mathrm{L}^{-1}$ pupuk cair Unitas Super memiliki gabah hampa yang cukup tinggi mencapai $35 \%$ dan hasil panen hanya mencapai 3,83 $\mathrm{t}$ ha $^{-1}$. Oleh karena itu, perlu diketahui pengaruh dari pemberian pupuk cair C.odorata dan pupk $\mathrm{KCl}$ terhadap kemampuannya menekan kehampaan dan meningkatkan hasil gabah padi ungu Black Madras.

Tujuan penelitian ini adalah untuk mengetahui pengaruh pemberian pupuk cair Chromolaena odorata dan kalium dalam menekan kehampaan dan meningkatkan hasil padi ungu Black Madras.

\section{BAHAN DAN METODE}

Penelitian dilaksanakan selama 3 bulan di Kelurahan Lubuk Lintah Kota Padang dengan ketinggian tempat $\pm 20 \mathrm{~m} \mathrm{dpl}$. Bahan tanam yang digunakan pada penelitian ini adalah benih padi Black Madras. Bahan lain yang digunakan adalah pupuk cair $C$. odorata (PCCO), pupuk urea (100 kg ha-1), ZA (50 kg ha $\left.{ }^{-1}\right)$, SP36 (150 kg ha $\left.{ }^{-1}\right)$ dan KCl. Alat yang digunakan adalah alat-alat budidaya, ember, waring, papan label, timbangan analitik, meteran. Rancangan penelitian yang digunakan adalah Rancangan Acak Lengkap faktorial.. Faktor pertama adalah konsentrasi pupuk cair Chromolaena

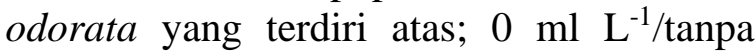


pupuk cair, $25 \mathrm{ml} \mathrm{L}^{-1}$ dan $50 \mathrm{ml} \mathrm{L}^{-1}$. Faktor kedua adalah dosis pupuk $\mathrm{KCl}$; yaitu $0 \mathrm{~kg} \mathrm{ha}^{-}$ ${ }^{1} /$ tanpa KCl, $50 \mathrm{~kg} \mathrm{ha}^{-1}, 100 \mathrm{~kg} \mathrm{ha}^{-1}$ dan 150 $\mathrm{kg} \mathrm{ha}^{-1}$. Setiap perlakuan diulang tiga kali, sehingga terdapat 36 satuan percobaan dengan ukuran plot 1 × $2 \mathrm{~m}$ dan jarak antar petak $35 \mathrm{~cm}$.

Pembuatan PCCO dilakukan dengan memfermentasi C.odorata, batang pisang, sabut kelapa dan pupuk kandang selama 1 bulan secara semi anaerob. Hasil fermentasi tersebut dimasukan ke dalam kontainer dan ditambah air dengan perbandingan air dan bahan 1:1. Setelah itu, bahan diberikan mikroorganisme lokal (MOL) dan urine sapi sebanyak $10 \%$ dan difermentasikan kembali selama 2 bulan (Jamilah et al. 2013).

Penelitian dilaksanakan dengan menyemai terlebih dahulu benih padi selama 14 hari, kemudian dipindah tanam ke lapangan dengan jarak tanam $20 \mathrm{~cm}$ x $20 \mathrm{~cm}$ sebanyak 2 bibit per rumpun. Pemupukan pertama dilakukan setelah 1 MST dengan dosis $100 \%$ SP36 dan $\mathrm{KCl}$ (sesuai perlakuan) dan 50\% Urea dan ZA. Pemberian pupuk cair dilakukan saat padi berumur 2 MST dan diberikan secara berkala sampai memasuki fase primordia bunga \pm 40 HST (hari setelah tanam) dengan interval 2 MST (minggu setelah tanam). Tanaman mulai digenangi pada mulai umur 10 HST hingga memasuki pengisian gabah. Pada saat pemberian pupuk buatan air dikeluarkan hingga kondisi tanah macak-macak.

Pengamatan dilakukan pada karakter tinggi tanaman, jumlah anakan dan anakan produktif, umur $75 \%$ berbunga, panjang malai, persentase gabah hampa, jumlah gabah per malai, umur panen, bobot 1000 biji dan bobot gabah kering panen per plot dan per ha. Data dianalisis secara statistik menggunakan uji $\mathrm{F}$ taraf nyata 5\% dan dilanjutkan dengan uji Beda Nyata Terkecil (BNT) dengan taraf $5 \%$.

\section{HASIL DAN PEMBAHASAN}

Secara umum, pertumbuhan vegetatif tanaman padi ungu Black Madras tidak memberikan respon terhadap pemberian pupuk $\mathrm{KCl}$, tetapi memberikan respon yang baik terhadap pemberian pupuk cair Chromolaena odorata (PCCO). Aplikasi PCCO memberikan pengaruh nyata terhadap jumlah anakan dan anakan produktif. Sementara itu, interaksi antara pemberian PCCO dengan kalium memberikan pengaruh yang nyata terhadap tinggi tanaman (Tabel 1).

Peningkatan konsentrasi PCCO mendorong pertumbuhan tanaman padi. Pemberian pupuk $\mathrm{KCl}$ hingga $150 \mathrm{~kg} \mathrm{ha}{ }^{-1}$ dapat mengurangi kebutuhan PCCO hingga $50 \%$. Secara umum, pemberian konsentrasi $25 \mathrm{ml} \mathrm{L}^{-1}$ PCCO lebih baik jika disertai dengan pemberian pupuk KCl. Pembentukan anakan produktif semakin meningkat, jika konsentrasi PCCO ditingkatkan menjad 50 $\mathrm{ml} \mathrm{L}^{-1}$. Hal ini membuktikan bahwa pemberian pupuk cair pada daun tanaman padi Black Madras lebih efektif dibandingkan dengan pemberian pupuk melalui tanah. Pupuk cair yang diberikan langsung disemprotkan ke daun, menyebabkan bagian daun mendapat nutrisi dalam waktu yang tepat dan menggunakannya segera sesuai dengan aktivitas metabolismenya. Hal tersebut sesuai dengan penjelasan Wójcik (2004), Gutiérrez-Gamboa (2017), Pandey et al. 2013), bahwa pupuk cair lebih efektif diberikan melalui daun jika pupuk atau unsur hara yang tersedia di dalam tanah rendah. Mineral yang berasal dari pupuk cair yang diberikan melalui daun akan mengalami penetrasi melalui plasma membran dari sel epidermis daun. Faktor lingkungan, aspek biologi tanaman, sifat larutan yang disemprotkan mempunyai efek penting pada efisiensi pemupukan lewat daun.

Pada Gambar 1, terlihat bahwa padi Black Madras pada umur 30 HST masih memiliki daun berwarna hijau dan berubah warna menjadi ungu seiring dengan pertumbuhan tanaman tersebut. Warna ungu pada daun padi Black Madras diakibatkan oleh adanya pigmen antosianin. 


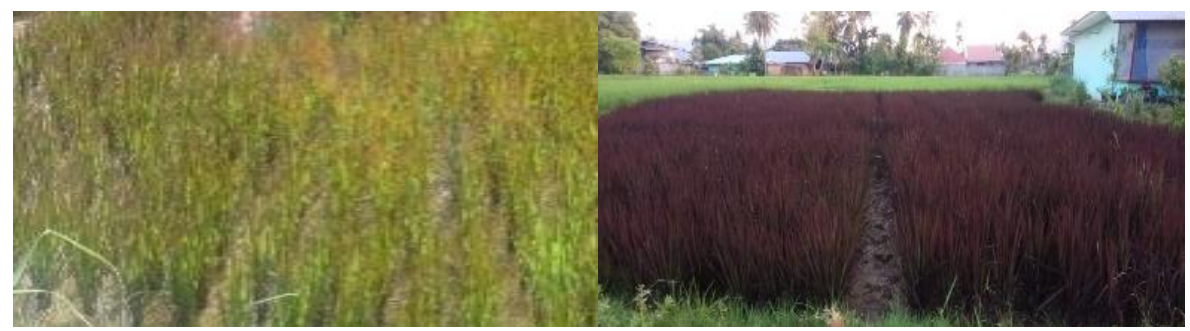

Gambar 1 Tampilan padi ungu Black Madras fase vegetatif saat 30 dan 60 HST

Pemberian PCCO memberikan pengaruh yang nyata terhadap karakter panjang malai, jumlah gabah per malai dan persentase gabah hampa padi Black Madras, tetapi pupuk kalium tidak memberikan pengaruh yang nyata (Tabel 2). Pemberian 50 $\mathrm{ml} \mathrm{L}^{-1} \quad$ PCCO efektif memberikan pertambahan panjang malai dan jumlah gabah secara nyata dibandingkan konsentrasi yang lebih rendah. Perlakuan PCCO $25 \mathrm{ml}$ $\mathrm{L}^{-1}$ dan $50 \mathrm{ml} \mathrm{L}^{-1}$ tidak memberikan pengaruh yang berbeda terhadap karakter gabah hampa.

Tabel 1 Pengaruh pupuk cair Chromolaena odorata dan kalium terhadap pertumbuhan vegetatif tanaman padi ungu Black Madras pada umur 8 MST

Tinggi tanaman $(\mathrm{cm})$

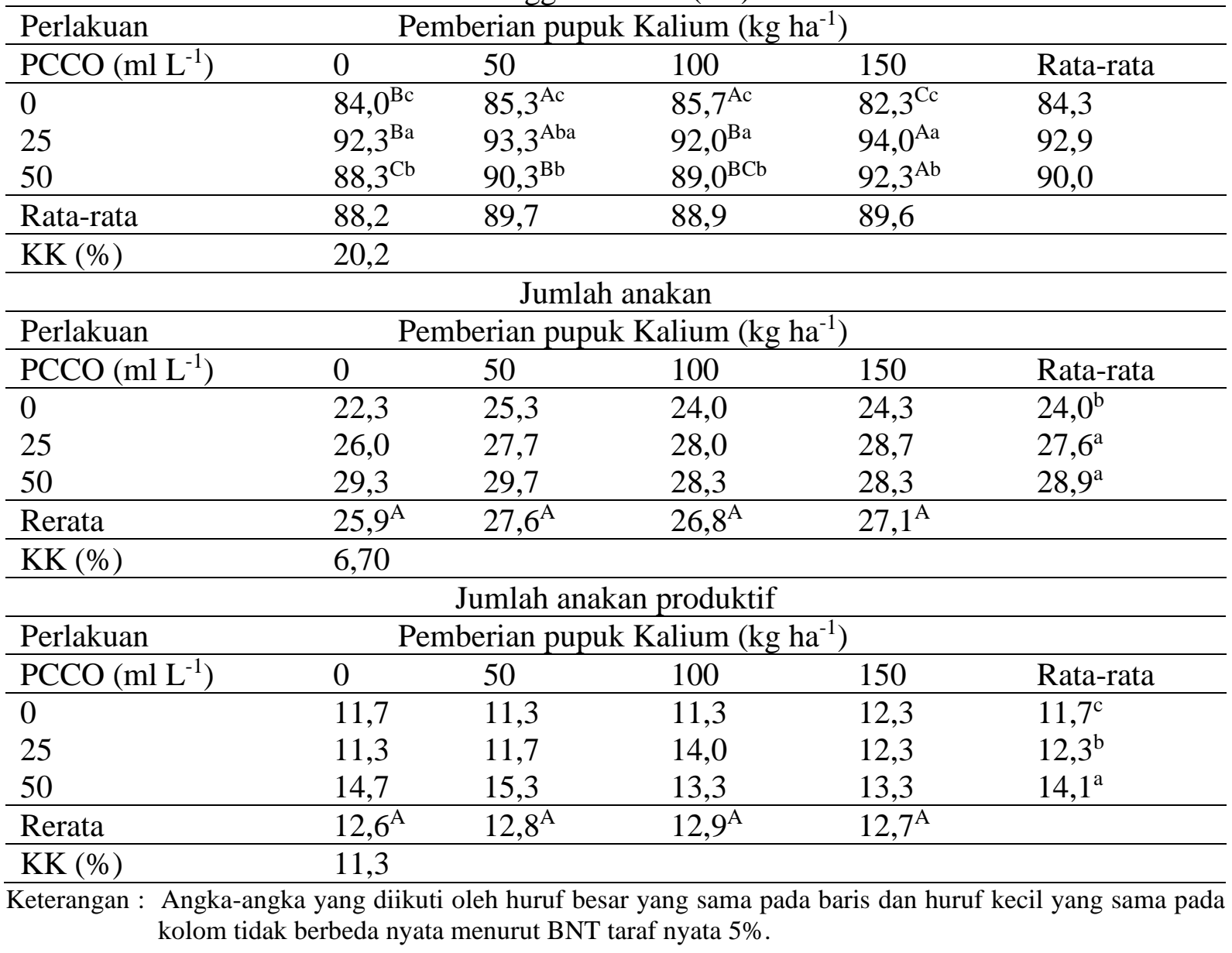

Pemberian $25 \mathrm{ml} \mathrm{L}^{-1}$ PCCO mampu menekan kehampaan gabah padi ungu Black Madras sebesar 55\% dibandingkan dengan yang tidak diberi PCCO. Hal ini menunjukkan bahwa PCCO terbukti efektif dalam menekan kehampaan padi di lapangan. Hasil tersebut sesuai dengan pernyataan Legaz dan Qui (2016), Gutiérrez-gamboa et 
al. (2016), Heidari et al. (2014), Putri dan Jamilah (2018), bahwa pupuk lebih efektif diberikan melalui daun dibandingkan tanah. Kehilangan pupuk melalui tanah dapat diakibatkan oleh tingginya tingkat pencucian, karena adanya air mengalir saat air irigasi dialirkan ke setiap petakan sawah. Kehampaan gabah dapat disebabkan oleh faktor internal tanaman atau faktor eksternal. Faktor internal antara lain genetik. Setiap tipe padi meiliki tingkat kehampaan berbeda.
Faktor eksternal kehampaan gabah adalah serangan walang sangit atau hama pengisap dan unsur hara. Pada fase matang susu, gabah dihisap oleh hama pengganggu dan mengakibatkan banyak gabah hampa. Unsur hara yang tidak mencukupi dapat mengakibatkan tanaman tumbuh merana, sehingga fotosintat yang dihasilkannya juga rendah. Hal tersebut berakibat pada pengisian gabah.

Tabel 2 Pengaruh pupuk cair Chromolaena odorata (PCCO) dan kalium terhadap panjang malai, jumlah gabah dan gabah hampa (\%) padi ungu Black Madras

Panjang malai $(\mathrm{cm})$

\begin{tabular}{|c|c|c|c|c|c|}
\hline \multicolumn{6}{|c|}{ Panjang malai $(\mathrm{cm})$} \\
\hline \multicolumn{6}{|c|}{ Dosis pupuk $\mathrm{KCl}\left(\mathrm{kg} \mathrm{ha}^{-1}\right)$} \\
\hline $\mathrm{PCCO}\left(\mathrm{ml} \mathrm{L}^{-1}\right)$ & 0 & 50 & 100 & 150 & Rata-rata \\
\hline 0 & 80,0 & 75,0 & 76,0 & 79,0 & $77,5^{\mathrm{c}}$ \\
\hline 25 & 81,5 & 79,5 & 81,0 & 82,5 & $81,1^{b}$ \\
\hline 50 & 85,5 & 83,5 & 86,5 & 82,0 & $84,4^{\mathrm{a}}$ \\
\hline Rata-rata & 82,3 & 79,3 & 81,2 & 81,2 & \\
\hline KK $(\%) \quad 6,01$ & & & & & \\
\hline \multicolumn{6}{|c|}{ Jumlah gabah per malai } \\
\hline \multicolumn{6}{|c|}{ Dosis pupuk $\mathrm{KCl}\left(\mathrm{kg} \mathrm{ha}^{-1}\right)$} \\
\hline $\operatorname{PCCO}\left(\mathrm{ml} \mathrm{L}^{-1}\right)$ & 0 & 50 & 100 & 150 & Rata-rata \\
\hline 0 & 159,7 & 154,3 & 158,3 & 170,3 & $160,7^{\mathrm{c}}$ \\
\hline 25 & 185,3 & 183,3 & 176,0 & 189,3 & $183,5^{\mathrm{b}}$ \\
\hline 50 & 192,7 & 185,7 & 197,0 & 192,3 & $191,9^{\mathrm{a}}$ \\
\hline Rerata & 179,2 & 174,4 & 177,1 & 184,0 & \\
\hline KK (\%) & 7,9 & & & & \\
\hline \multicolumn{6}{|c|}{ Persentase gabah hampa } \\
\hline \multicolumn{6}{|c|}{ Dosis pupuk $\mathrm{KCl}\left(\mathrm{kg} \mathrm{ha}^{-1}\right)$} \\
\hline $\operatorname{PCCO}\left(\mathrm{ml} \mathrm{L}^{-1}\right)$ & 0 & 50 & 100 & 150 & Rata-rata \\
\hline 0 & 8,5 & 9,7 & 9,5 & 9,7 & $9,3^{\mathrm{b}}$ \\
\hline 25 & 4,2 & 3,7 & 3,7 & 5,7 & $4,2^{\mathrm{a}}$ \\
\hline 50 & 5,5 & 4,8 & 5,8 & 4,8 & $5,2^{\mathrm{a}}$ \\
\hline Rata-rata & 6,0 & 5,9 & 6,3 & 6,8 & \\
\hline $\mathrm{KK}(\%)$ & 21,1 & & & & \\
\hline
\end{tabular}

Keterangan: Angka-angka yang diikuti oleh huruf besar yang sama pada baris dan huruf kecil yang sama pada kolom tidak berbeda nyata menurut BNT taraf nyata $5 \%$.

Jumlah gabah dan panjang malai semakin meningkat seiring dengan meningkatkan konsentrasi PCCO yang diberikan. Hal tersebut menunjukkan bahwa konsentrasi pupuk cair yang lebih pekat mampu merangsang pembentukan malai, sehingga terjadi pertambahan jumlah dan panjang malai.. Gabah yang dihasilkan merupakan hasil kumpulan fotosintat yang dihimpun dalam setiap bulir gabah yang sangat dipengaruhi oleh ketersediaan hara yang cukup dan berimbang (Jamilah et al. 2014).

Pupuk cair yang diberikan mampu menyediakan kebutuhan nutrisi tanaman padi, sehingga mempengaruhi pertumbuhan beberapa karakter tanaman, tetapi pertumbuhan tanaman tidak dipengaruhi oleh 
pupuk kalium. Tanaman padi tidak membutuhkan tambahan kalium dari pupuk disebabkan sawah mendapatkan air irigasi yang telah membawa mineral kalium (Nishiuchi et al. 2012). Oleh karena itu, dapat dikatakan bahwa pemberian pupuk cair pada daun padi secara periodik lebih efektif dilakukan. Seperti yang telah dijelaskan oleh (Ariyanto 2012), bahwa pemberian pupuk bertahap lebih efektif jika dibandingkan dengan pemberian pupuk dalam jumlah banyak pada satu kali pemberian saja. Hal ini disebabkan karena tanaman tidak mampu menyerap hara dari dalam tanah dalam jumlah banyak pada satu waktu tertentu. Kebutuhan hara tanaman sangat ditentukan oleh fase pertumbuhan tanaman tersebut.

Tabel 3 Pengaruh pupuk cair Chromolaena odorata (PCCO) dan kalium terhadap umur berbunga, bobot 1000 biji dan gabah kering panen padi ungu

Umur berbunga (hari)

\begin{tabular}{|c|c|c|c|c|c|}
\hline \multicolumn{6}{|c|}{ Pemberian pupuk $\mathrm{KCl}\left(\mathrm{kg} \mathrm{ha}^{-1}\right)$} \\
\hline $\mathrm{PCCO}\left(\mathrm{ml} \mathrm{L}^{-1}\right)$ & 0 & 50 & 100 & 150 & Rerata \\
\hline 0 & 59,7 & 59,3 & 59,7 & 59,7 & $59,6^{\mathrm{b}}$ \\
\hline 25 & 58,7 & 59,0 & 59,3 & 59,0 & $59,0^{\mathrm{b}}$ \\
\hline 50 & 58,3 & 58,3 & 59,0 & 58,3 & $58,5^{\mathrm{a}}$ \\
\hline Rerata & 58,9 & 58,9 & 59,3 & 59,0 & \\
\hline $\mathrm{KK}(\%)$ & 1,0 & & & & \\
\hline \multicolumn{6}{|c|}{ Bobot 1000 biji (g) } \\
\hline \multicolumn{6}{|c|}{ Pemberian pupuk $\mathrm{KCl}\left(\mathrm{kg} \mathrm{ha}^{-1}\right)$} \\
\hline $\mathrm{PCCO}\left(\mathrm{ml} \mathrm{L}^{-1}\right)$ & 0 & 50 & 100 & 150 & Rerata \\
\hline 0 & 26,5 & 26,9 & 27,7 & 26,2 & $26,8^{\mathrm{a}}$ \\
\hline 25 & 26,7 & 27,3 & 28,8 & 27,4 & $27,6^{\mathrm{a}}$ \\
\hline 50 & 27,2 & 27,7 & 27,1 & 27,7 & $27,4^{\mathrm{a}}$ \\
\hline Rerata & $26,8^{\mathrm{A}}$ & $27,3^{\mathrm{A}}$ & $27,9^{\mathrm{A}}$ & $27,1^{\mathrm{A}}$ & \\
\hline $\mathrm{KK}(\%)$ & 3,3 & & & & \\
\hline \multicolumn{6}{|c|}{ Bobot Gabah kering panen $(\mathrm{GKP})\left(\mathrm{t} \mathrm{ha}^{-1)}\right.$} \\
\hline \multicolumn{6}{|c|}{ Pemberian pupuk $\mathrm{KCl}\left(\mathrm{kg} \mathrm{ha}^{-1}\right)$} \\
\hline PCCO $\left(\mathrm{ml} \mathrm{L}^{-1}\right)$ & 0 & 50 & 100 & 150 & Rerata \\
\hline 0 & $6,0^{\mathrm{Ba}}$ & $6,1^{\mathrm{Ba}}$ & $6,8^{\mathrm{Ba}}$ & $6,5^{\mathrm{Ba}}$ & 6,4 \\
\hline 25 & $7,0^{\mathrm{Aa}}$ & $7,1^{\mathrm{Aa}}$ & $7,9^{\mathrm{Aa}}$ & $7,2^{\mathrm{Aa}}$ & 7,3 \\
\hline 50 & $6,2^{\mathrm{Ab}}$ & $7,7^{\mathrm{Aa}}$ & $7,0^{\mathrm{ABab}}$ & $7,9^{\mathrm{Aa}}$ & 7,3 \\
\hline Rerata & 6,4 & 7,0 & 7,2 & 7,2 & \\
\hline
\end{tabular}

Keterangan : Angka-angka yang diikuti oleh huruf besar yang sama pada baris dan huruf kecil yang sama pada kolom tidak berbeda nyata menurut BNT taraf nyata $5 \%$.

Pemberian PCCO juga berpengaruh terhadap umur berbunga dan hasil gabah kering padi Black Madras, tetapi tidak berpengaruh terhadap bobot 1000 biji (Tabel 3).Umur berbunga padi ungu Black Madras berkisar antara 58-59 HST dan umur panennya berkisar antara 85-86 HST. Berarti setelah $75 \%$ tanaman merata berbunga, maka 27 hari kemudian padi ungu Black Madras sudah bisa dipanen. Jika dibandingkan dengan jenis padi lainnya, padi Black Madras tergolong tanaman padi genjah atau umur pendek (Nutani 2018). Konsentrasi $25 \mathrm{ml} \mathrm{L}^{-1}$ PCCO menghasilkan gabah kering giling lebih tinggi dibandingkan dengan konsentrasi $50 \mathrm{ml} \mathrm{L}^{-1}$. Hasil gabah kering yang tinggi disebabkan karena gabah hampa yang dihasilkannya sedikit. Pada pemberian konsentrasi $50 \quad \mathrm{ml}^{-1} \quad \mathrm{~L}^{-1} \quad \mathrm{PCCO}$ terjadi peningkatan kehampaan, sehingga dapat menurunkan produksi gabah kering panen. Oleh karena itu, ada hubungan yang erat 
antara kehampaan dengan produksi gabah padi ungu. Semakin tinggi kehampaan gabah maka semakin rendah produksi gabah padi.

Pupuk $\mathrm{KCl}$ dapat meningkatkan hasil gabah kering dengan dosis optimum $100 \mathrm{~kg}$ $\mathrm{ha}^{-1}$. Menurut Notohadiprawiro et al. (2006), hampir 78\% K diserap melalui proses difusi dan $20 \%$ melalui aliran massa. Unsur $\mathrm{K}$ merupakan unsur hara kedua terbesar yang dibutuhkan oleh tanaman. Apabila takaran pupuk ditingkatkan lagi menjadi $150 \mathrm{~kg} \mathrm{ha}^{-}$ ${ }^{1}$, tidak menyebabkan peningkatan hasil lagi dan beresiko menyebabkan kelebihan pupuk. Kelebihan pupuk akan mengganggu keseimbangan unsur hara lain. Oleh karena itu, pemupukan berimbang sangat dianjurkan agar keberadaan unsur yang satu tidak menekan unsur hara lain sehingga menjadi tidak tersedia.

Padi Black Madras masih tetap berwarna ungu sampai memasuki fase panen, tetapi warnah gabah tetap coklat dan warna berasnya tetap putih. Pemupukan $\mathrm{KCl}$ memberikan respon yang positif dalam meningkatkan hasil GKP. Pupuk kalium sebanyak $100 \mathrm{~kg} \mathrm{ha}^{-1}$ jika diiringi dengan 25 $\mathrm{ml} \mathrm{\textrm {L } ^ { - 1 }}$ PCCO memberikan hasil GKP tertinggi yaitu $7,88 \mathrm{~kg} \mathrm{ha}^{-1}$. Peningkatan pemberian kalium sampai $150 \mathrm{~kg} \mathrm{ha}^{-1}$, tidak diikuti oleh peningkatan bobot gabah padi. Hal tersebut menunjukkan bahwa pada dosis tersebut, pupuk kalium sudah dianggap berlebih untuk tanaman padi ungu Black Madras. Pemberian salah satu unsur hara yang berlebihan akan menekan ketersediaan unsur lain pada tanaman, akibat pemupukan yang tidak berimbang. Hal ini sudah dijelaskan oleh Stevens et al. (2002), Notohadiprawiro et al. (2006), Fixen (2015), Ariyanto (2012), Griffith (2015), bahwa unsur kalium merupakan regulator pada transpor ion. Jika unsur $\mathrm{K}$ diserap tanaman berlebih maka akan menekan ketersediaan unsur Mg pada tanaman atau sebaliknya.

\section{KESIMPULAN}

Pemberian $25 \mathrm{ml} \mathrm{L}^{-1}$ pupuk cair $C$. odorata efektif dalam menekan kehampaan padi hingga 55\%. Pemberian pupuk kalium sebanyak $100 \mathrm{~kg} \mathrm{ha}^{-1}$ yang diiringi dengan 25 $\mathrm{ml} \mathrm{L} \mathrm{L}^{-1}$ PCCO memberikan hasil GKP tertinggi yaitu $7,88 \mathrm{~kg} \mathrm{ha}^{-1}$.

\section{Ucapan Terima Kasih}

Ucapan terima kasih disampaikan kepada LPPM (Lembaga Penelitian dan Pengabdian kepada Masyarakat) yang sudah mendanai kegiatan penelitian ini. Juga terima kasih disampaikan kepada pengelola Laboratorium Unitas yang telah memfasilitasi sehingga kegiatan ini dapat terlaksana dengan lancar.

\section{DAFTAR PUSTAKA}

Ariyanto DP. 2012. Pupuk Dan Pemupukan. $1-9$.

Fixen P. 2015. Soil Testing. In Efficient Fertilizer Use Manual (Vol. 1, pp. 1-7). Mosaic, Mossaicco.com.

Griffith B. 2015. Fertilizer Use and the Environment Phosphorus and the Environment. In Mosaic (pp. 1-5). Mossaicco.com.

Gutiérrez-gamboa G, Garde-cerdán T, Gonzalo-diago A. Martínez-gil AM. 2016. Effect of different foliar nitrogen applications on the must amino acids and glutathione composition in Cabernet Sauvignon vineyard. LWT Food Science and Technology. 75:147154

Gutiérrez-gamboa, G., Garde-cerdán, T., Portu, J., Moreno-simunovic, Y., \& Martínez-gil, A. M. (2017). Foliar nitroen application in Cabernet Sauvignon vines: Effect on wine flavonoid and amino acid content. Food Research International. 96:46-53.

Gutiérrez-Gamboa G, Garde-Cerdán T, Portu J, Moreno-Simunovic Y, Martínez-Gil AM. 2017. Foliar nitrogen application in Cabernet Sauvignon vines: Effects on wine flavonoid and amino acid content. Food Research International. 96:46-53. Heidari S, Azizi M, Soltani F, Hadian J. 2014. Foliar application of $\mathrm{Ca}\left(\mathrm{NO}_{3}\right)_{2}$ and $\mathrm{KNO}_{3}$ affects growth, essential oil content and oil composition of French 
tarragon. Industrial Crops and Products. 62(3):526-532.

Jamilah. (2017). Peluang Budidaya Tanaman Padi sebagai Penyedia Beras dan Pakan Ternak Menunjang Kedaulatan Pangan. Penerbit Deeppublish CV Budi Utama, Jogyakarta, Edisi 1 Cetakan 1, 92 halaman.

Jamilah, Kurniawan B, Zahanis Z. 2018. Pengaruh pupuk organik cair unitas super asal chromolaena odorata terhadap pertumbuhan dan hasil padi hitam (Oryza sativa L.). Jurnal Agroteknologi. 8(2), 15-20.

Jamilah, Juniarti. 2014. Test of liquid organic fertilizer originated c.odorata and coconut fiber with various composition by length fermentation. Journal of Environmental Research and Development. 9(1):1-6.

Jamilah, Maradona C, Zahanis, Ernita M. 2014. Penetapan konsentrasi dan intreval pemberian pupuk organik cair asal sabut kelapa dan tithonia untuk meningkatkan hasil padi ladang (Oryza sativa L.). Prosiding Seminar Nasional Pebangunan Bio-Industri untuk Mewujudkan Kedaulatan Pangan Indonesia (pp. 53-59). Payakumbuh: Politani Pertanian Negeri Payakumbuh.

Jamilah, Napitupulu, Y., \& Marni, Y. (2013). peranan Gulma C.odorata dan sabut kelapa sebagai bahan baku pupuk organik cair mengganti pupuk Kalium untuk pertumbuhan dan hasil padi ladang. Prosiding Seminar Nasional Optimalisasi Sistem Pertanian Terpadu (pp. 99-106). Payakumbuh, Sumatera Barat: Politani Pertanian Negeri Payakumbuh.

Jamilah, Soleh R., Herman W. 2017. Respon tanaman padi (Oryza sativa L.) kabir 07 terhadap pupuk organik cair crocober plus khusus kota padang dengan iklim af. Jurnal Solum. 7(1): 18-27.

King seeds. (2019). Black Madras (ornamental Rice). King Seeds whole seed Merchants and growers since 1888. https://www.kingsseedsdirect.com/blac k-madras-ornamental-rice/p1314.

Legaz F, Qui A. 2016. Liquid organic fertilizers for sustainable agriculture: nutrient uptake of organic versus mineral fertilizers in citrus trees. 11(10):1-20.

Nishiuchi S, Yamauchi T, Takahashi H, Kotula L, Nakazono M. 2012. Mechanisms for coping with submergence and waterlogging in rice. Rice. 5(1):2.

Notohadiprawiro, T. (2006). Sarian kumpulan makalah lahan basah, 1-5. Penerbit Program Studi Ilmu Tanah, Universitas Gadjah Mada.

Notohadiprawiro T, Soeprapto S, Endang S. 2006. Pengelolaan kesuburan tanah dan peningkatan efisiensi pemupukan 1 . In Ilmu Tanah (pp. 1-19). Jogyakarta: Universitas Gadjah Mada.

Pandey, R., Krishnapriya, V., \& Bindraban, P. S. (2013). Biochemical Nutrient Pathways in Plants Applied as Foliar Spray: Phosphorus and Iron Biochemical Nutrient Pathways in Plants Applied as Foliar Spray: Phosphorus and Iron, Division of Plant Physiology, Indian Agricultural Research Institute, New Delhi 110012, INDIA, Washington, D.C., USA.23 p.

Putri LA, Jamilah HW. 2018. Pengaruh pupuk organik cair dan Trichoderma sp. terhadap pertumbuhan dan hasil melon (Cucumis melo L.). Jurnal Bibiet. 3(1):17-24.

Reuveni M. 1998. Foliar fertilizer theraphya concept in integrated pest management. Crop Protection. 17(2): 111-118.

Shahid M, Dumat C, Khalid S, Schreck E, Xiong T, Niazi NK. 2017. Foliar heavy metal uptake, toxicity and detoxification in plants: A comparison of foliar and root metal uptake. Journal of Hazardous Materials. 325: 36-58.

Stevens, G., Motavalli, P., Scharf, P., Nathan, M., \& Dunn, Da. (2002). Crop nutrient deficiencies \& toxicities. Extension Published by MU Extension, University of Missouri-Columbia. 20 p. 
Wójcik P. 2004. Uptake of mineral nutrients from foliar fertilization. Journal of Fruit and Ornamental Plant Research. 12:201-218. 